\title{
Entrepreneurship in Brazil: A Worthy Endeavor?
}

\author{
Igor Serpa Moraes ${ }^{1}$, Roque Pinto de Camargo Neto ${ }^{2}$, Vivian S. Queiroz Orellana ${ }^{1} \&$ Gabrielito Rauter Menezes $^{3}$ \\ ${ }^{1}$ Federal University of Rio Grande, Rio Grande, Rio Grande do Sul, Brazil \\ ${ }^{2}$ School of Business ESAMC, Sorocaba, São Paulo, Brazil \\ ${ }^{3}$ Federal University of Pelotas, Pelotas, Rio Grande do Sul, Brazil \\ Correspondence: Roque Pinto de Camargo Neto, School of Business ESAMC, Sorocaba, R. da Penha, 1181 - \\ Centro, 18010-004, Brazil. Tel: 55-15-99617-9945. E-mail: roquecneto@gmail.com
}

Received: April 11, 2020

doi:10.5539/ijef.v12n7p98
Accepted: June 26, 2020

Online Published: June 30, 2020

URL: https://doi.org/10.5539/ijef.v12n7p98

\begin{abstract}
This study analyzes if there are differences between the income of entrepreneurs and wage earners in Brazil. Using data from the 2015 National Household Sample Survey database, we estimate a Mincer equation, correcting for self-selection, which explains the choice of entrepreneurship in the function of earnings related to salaried work. Subsequently, the wage differential per category is decomposed using the Oaxaca-Blinder procedure. To complete the analysis, a detailed decomposition is used to identify the explained and unexplained components of the wage gap. The results indicate that personal, cultural, and demographic characteristics affect the entrepreneurial occupational choice as well the differential in the income of entrepreneurs and employees. On average, entrepreneurs earn approximately $19.68 \%$ more than salaried workers.
\end{abstract}

Keywords: entrepreneurship, equation of wages, decomposition of Oaxaca-Blinder

\section{Introduction}

\subsection{Introduce the Problem}

Entrepreneurship has played a significant role in economic growth and development of countries, generating jobs and implementing new technologies. Accordingly, as a stimulator of economic growth, it has attracted the interest of economists, managers, and policymakers. According to Schumpeter (1997), entrepreneurship plays an essential role in economic development; its role starts with innovation, whereby it contributes to the introduction of new resources or differentiated combinations of existing productive resources. As Dornelas (2014) stated, we are currently living in the era of entrepreneurship, which is creating new labor relations and jobs, breaking paradigms, and generating wealth for the society.

In the entrepreneurship economics literature, several papers focus on the occupational choice of an individual, aiming to maximize the utility function between an entrepreneur and an employee. Generally, the models used for this analysis are of discrete choice and prioritize the estimation of a wage equation, seeking to determine the characteristics that lead individuals to choose entrepreneurship as an occupation (Parker, 2009). Empirical analyses of the determinants of the entrepreneurship occupational choice in developed economies indicate that, in addition to regional characteristics, personal characteristics play an important role. Therefore, the decision to become an entrepreneur depends on the fact that the individual seeks to maximize his or her usefulness; accordingly, the economic returns generated by entrepreneurial activities are compared with those of salaried employment (Tamvada, 2007).

\subsection{Explore Importance of the Problem}

Given the relevance of this subject, the current work is significant as only a few works have studied this subject in the Brazilian context. Our study investigates the factors that influence the decision to become an entrepreneur or employee, also investigating if there is a difference in wages between the two occupations in Brazil, as suggested by the entrepreneurship economics literature. The findings can guide the formulation of public policies aimed at a better understanding of entrepreneurial activities in the country. Unlike Giuberti and Menezes-Filho (2005), Fossen (2009), Caliendo, Fossen, Kritikos, and Wetter (2014), and Almeida and Besarria (2014), who evaluate wage differentials by gender, we study the wage gap between entrepreneurs and salaried individuals, and verify the existence of this gap through an empirical analysis. 
For the analysis, we use data from the National Household Sample Survey (PNAD) for 2015. The effects of individual characteristics, family characteristics, and other demographic aspects are estimated using a probit model of occupational choice. Similarly, we estimate the income equations to explain the choice of entrepreneurship as a function of earnings relative to that of salaried workers. Additionally, we explain the salary differential between entrepreneurs and employees using the Oaxaca-Blinder decomposition, specifically highlighting the entrepreneur's remuneration. Finally, we use a detailed decomposition, which allows us to identify the explained and unexplained components of the wage gap.

Based on an analysis of the labor market and on the theoretical framework of entrepreneurship economics, we assume that an average entrepreneur earns more than a salaried worker. To provide evidence of this gap, we verify, based on a simple average of our sample, that entrepreneurs earn a salary of $R \$ 2,183.00$, while salaried individuals receive roughly $\mathrm{R} \$ 1,545.00$. This represents a salary differential of approximately $29.2 \%$. The results of our study indicate that, as expected, there is a wage gap between these two occupations; however, entrepreneurial compensation is only $19.68 \%$ higher than that of salaries employees.

\subsection{Describe Relevant Scholarship}

Entrepreneurship has attracted significant attention in economics research. Scholars have sought to identify the determining factors that influence an individual's decision to become an entrepreneur (Gieure, Benavides-Espinosa, \& Roig-Dobón, 2020; Parker, 2009). The dependent variable in this study indicates whether the individual is engaged in any entrepreneurial activity and is regressed in relation to a set of explanatory variables that may include individual characteristics or contextual variables. However, the definition of an entrepreneur varies greatly (Bernat, Lambardi, \& Palacios, 2016).

A broad definition of an entrepreneur proposed by Fossen (2009) and Caliendo, Fossen, Kritikos, and Wetter (2014) considers every self-employed individual an entrepreneur. Other studies focus on the concept of nascent entrepreneurs (Bönte \& Piegeler, 2013; Verheul, Thurik, Grilo, \& Van der Zwan, 2012). Such classifications seek to identify potential groups of entrepreneurs, regardless of the state of their current employment. Meanwhile, other papers focus on analyzing entrepreneurs by necessity and entrepreneurs by opportunity, taking need as the dependent variable (Elam \& Terjesen, 2010; Terjesen \& Espinosa, 2010).

In the context of economic theory, microeconomics provides tools for analyzing the decision-making process of occupational choice. In a scenario where individuals seek to maximize their usefulness, microeconomics, through its instruments, helps us determine the determinants that influence the decision to become an entrepreneur (i.e., whether entrepreneurship leads to a relative gain in relation to being employed, thereby maximizing individuals' usefulness).

Pereira and Oliveira (2016), motivated by the models of wage differentials between men and women, show that the average wage of individuals differs by education. While Almeida and Besarria (2014) indicate that the average wage differential between men and women is due to some form of discrimination, Bernat et al. (2016) explain this differential by education, job satisfaction, risk aversion, ownership of means of transportation, and engagement in family-owned businesses. Meireles (2014) and Niederle and Vesterlund (2007) explain the gender income differential by the tendency of men to work in more competitive jobs, unlike women, who avoid working in such jobs.

The articles of Bernat et al. (2016), Fossen (2009), Giuberti and Menezes-Filho (2005), Crespo and Reis (2004), Silva and Lima (2012), Cacciamali, Tatei, and Rosalino (2009) stand out in the wage gap literature. The method of decomposition of Blinder (1973) and Oaxaca (1973) has been widely used in the study of the wage differential (see Pereira \& Oliveira, 2016 and Almeida \& Besarria, 2014, among others). One variation of this method was implemented by Bartalotti (2007), who applied the Oaxaca-Blinder methodology to quantitative regressions using Brazilian data. Fairlie (2005) presents another extension of the Oaxaca-Blinder methodology, as in (Fritsch, Kritikos, \& Sorgner, 2015).

Within this scope, Bernat et al. (2016) highlight a set of factors associated with the decision to become an entrepreneur, as well as the variables that explain gender differences in business activity in Latin America. For this, they use logit models to estimate entrepreneurial activities under three different definitions of entrepreneurship. Taking this further, they estimate the gender gap using the Fairlie decomposition method. It is noteworthy that differences in observable characteristics explain 23\%-38\% of the disparity between genders.

Regarding the explanatory variables used to explain the entrepreneurial career choice, the literature shows the relevance of education level. However, the direction of its effect differs, according to different authors. According to Blanchflower (2004), education level has a positive relationship with business activity in the US, 
but the relationship is opposite in Europe. The author points out that this may be because individuals with higher educational levels get better job offers; however, they also have a greater capacity to identify entrepreneurial opportunities, thus creating a positive effect from both perspectives. Related to entrepreneurial education (Colombo \& Piva, 2020; Dou, Zhu, Zhang, \& Wang, 2019; Galvão, Marques, Ferreira, \& Braga, 2020; Mahfud, Triyono, Sudira, \& Mulyani, 2020).

One variable commonly used in estimates for business activity is age, since it is related to innovation and the self-perceived necessity of constantly updating knowledge. Thus, it is reasonable to expect that younger people would be more likely to become entrepreneurs. However, in theory, starting a business is simple for an individual who already has some experience in the field. Therefore, in this sense, a potential entrepreneur is more likely to be an older individual. Some studies report an inverted U-shaped relationship between age and entrepreneurial activity (Caliendo et al., 2014; Llussá, 2011; Poblete, Sena, \& Fernandez de Arroyabe, 2019; van der Zwan, Verheul, \& Thurik, 2012).

Other variables of interest are related to the labor market. Empirical evidence shows that there is a wage differential in the labor market between men and women, as well as between whites and non-whites: men and whites receive a higher wage. However, recent studies flag a reduction in gender- and race-based wage differentials caused by labor market discrimination in Brazil and in some other countries (Almeida \& Besarria, 2014).

Investigating the relationship between educational qualification and discrimination from 1990 to 2000 in the US, Carneiro, Heckman, and Masterov (2005) find evidence of indirect discrimination in the labor market since the wage differential between whites and non-whites (except for blacks) was determined by pre-market factors. Giuberti and Menezes-Filho (2005) compare the wage differential between men and women in Brazil and the US to ascertain whether the influencing factors are the same in both countries. They conclude that in both labor markets, during the analyzed period, there was a component of the wage gap between men and women not explained by the individual characteristics. However, in both countries, a trend of both explained and unexplained reduction in these wage differentials over time has been observed.

With respect to entrepreneurship and the gender differential, the work of Afandi and Kermani (2015) is noteworthy. The authors use the Oaxaca-Blinder decomposition methodology on individual data from 30 European countries. As in previous studies, they find that, on average, men are more likely to be entrepreneurs than women; they attribute this result to the fact that men are more prone to take on investment risks than women are. Other studies on entrepreneurship and the gender (Chatterjee \& Ramu, 2018; Monteith \& Camfield, 2019; Rosca, Agarwal, \& Brem, 2020).

Caliendo et al. (2014) and Fossen (2009) study the gender differential for a transition from wage-earner to entrepreneur. While Caliendo et al. (2014) use the Oaxaca-Blinder decomposition to explain the differential, Fossen (2009) uses the Fairlie decomposition. The results indicate that, although differences in risk tolerance and education increase the gender gap, variables such as type of employment or personality tend to reduce this difference. According to Fossen (2009), the greater risk aversion of women accounts for only $2 \%$ of entrepreneurial transition rates.

Considering the growing importance of entrepreneurship, this study identifies the factors that motivate an individual to choose the entrepreneurial occupation, highlighting conditioning variables for this choice, such as education level, age, and position in the family (Parker, 2009). For this, we use the Oaxaca-Blinder composition method, along with others of prominence. In doing so, we differentiate this work by exploiting the earnings differential between entrepreneurs and salaried individuals. Through a detailed decomposition, we demonstrate how much each observed variable contributes to the wage gap between entrepreneurs and wage earners.

\section{Method}

\subsection{Models of Discrete Choice}

According to (Parker, 2004; 2009), the most commonly-used models for this type of analysis are probit and logit models, indicating entrepreneurship as occupational choice. Binary variable models are often used for entrepreneurship research. Initially, a probit model, considered more appropriate, is used to estimate the dependent variable, the choice of entrepreneurship.

In this sense, we begin to consider the choice between these two occupations, entrepreneurship or wage earner, denominated by $j$, where $E$ represents entrepreneur, and any other remunerated employment will be indicated by $P$. Each individual present in this analysis has a vector that indicates their observable characteristics represented by $W_{i}$ and a utility function, expressed by $U i j=U(W i ; j)+u i j$ if the individuals in question exercise 
occupational choice $j$. It should also be noted that part of the utility function $U(. ;$.$) can be observed with the$ use of econometric resources since $u_{i j}$ is an unobserved utility. Finally, $Z_{i}^{*}$ is a variable denoting the relative advantage of an individual $i$ exercising occupation $E$ in relation to occupation $P$. Therefore,

$$
Z_{i}^{*}=U\left(W_{i} ; E\right)-U\left(W_{i} ; P\right)+U_{i E}-U_{i P}
$$

We can write the Equation (1), considering $U(. ;$.$) as linear and adopting the form \left(W_{i} ; j\right)=\beta_{j}^{\prime} W_{i}$, where $\beta_{j}$ are vectors of coefficients.

$$
Z_{i}^{*}=\alpha+\beta^{\prime} W_{i}+v_{i}
$$

where $\alpha:=E\left[U_{i E}-U_{i P}\right]$ being the term of intercept; $\beta^{\prime}:=\beta_{E}^{\prime}-\beta_{P}^{\prime}$ is another vector of coefficients; and $v_{i}:=U_{i E}-U_{i P}-\alpha \sim I I N\left(0, \delta^{2}\right)$ is the error term. $\beta$ is treated as a complex set of coefficients since the intercept is embedded in $W_{i}$. For Parker (2009), an individual $i$ will choose to be an entrepreneur rather than being wage earner if a variable $Z_{i}^{*} \geq 0$. We then define this binary variable as follows:

$$
Z_{i}^{*}= \begin{cases}1 \text { if the individual } \mathrm{i} \text { is observed in } E, & \text { if } Z_{i}^{*} \geq 0 \\ 1 \text { if the individual } \mathrm{i} \text { is observed in } P, & \text { if } Z_{i}^{*}<0\end{cases}
$$

The probability of an individual being an entrepreneur can be expressed by analyzing the characteristics represented in vector $W_{i}$ by:

$$
\operatorname{Pr}\left(Z_{i}=1\right)=\operatorname{Pr}\left(Z_{i}^{*} \geq 0\right)
$$

The model most suitable for the analysis of occupational choice and used in the present study is probit. The distribution of the error term follows a normal distribution $\operatorname{Pr}\left(Z_{i}=1\right)=\Phi\left(\frac{\beta^{\prime} W_{i}}{\sigma}\right)$ and $\operatorname{Pr}\left(Z_{i}^{*} \geq 0\right)=1-\Phi\left(\frac{\beta^{\prime} W_{i}}{\sigma}\right)$, where $\Phi($.$) indicates the cumulative distribution function of the standard normal distribution. \mathrm{W}_{i}$ is a vector containing the different characteristics of all individuals, expressed by the explanatory variables. Thus, $Z_{i}$ assumes a value of 1 if the individual in question is entrepreneur, and 0 if $s /$ he is a paid worker.

The maximum likelihood equation, used to estimate the probit model, takes the following form:

$$
\mathcal{L}=\sum_{i=1}^{n} \Phi\left(\frac{\beta^{\prime} W_{i}}{\sigma}\right)^{Z_{i}}\left[1-\Phi\left(\frac{\beta^{\prime} W_{i}}{\sigma}\right)\right]^{1-z_{i}}
$$

To achieve results that allow better analysis and interpretation of the estimated coefficients, the average marginal effects will be used. This enriches the analysis, since the previous estimation using maximum likelihood did not allow a direct interpretation of these coefficients. Thus, the marginal effect is expressed by:

$$
\frac{\partial E(Z / W)}{\partial W}=\Phi\left(W_{i} \beta\right) \beta
$$

$W_{i} \beta$ is defined as the vector of coefficients multiplied by a vector that has values for the dependent variables. Then, the marginal effect can be interpreted as the change in probability of an infinitesimal change in each independent variable for the continuous variables and a discrete change in probability for the dummy variables.

\subsection{Wage Equation}

To estimate the wage equation, we use the Heckman (1979) method to explain occupational choice because it is entrepreneurial in the function of the earnings relative to the salaried worker. Heckman's (1979) method is used to correct the information selection bias. The model is composed of two equations, one containing observable personal characteristics of the individuals, which indicate if the individual is an entrepreneur or wage worker, and a second regarding the salaries of these individuals, which also contributes to occupational choice.

As discussed by Heckman (1979), selection bias can occur for two reasons. The first is the self-selection of the individuals in the sample, where they themselves are selected to participate. The second is the criteria employed for sample selection; they may result in the selection of only particular individuals, thus acting as a form of self-selection.

The correction variables for the selection bias are extracted from the univariate probit model. Such variables are commonly called inverse Mills ratios and are represented by:

$$
\begin{gathered}
\lambda_{1} \equiv \frac{\varphi(\hat{P})}{\Phi(\hat{P})} \\
\lambda_{2} \equiv\left[-\frac{\varphi(\hat{P})}{1-\Phi(\widehat{P})}\right]
\end{gathered}
$$


where $\varphi($.$) represents the standard normal density function and \Phi($.$) the cumulative normal density function.$ $\lambda_{1}$ is for entrepreneurs and $\lambda_{2}$ for employees.

After calculating the ratios, we include them in the regressions as explanatory variables and use them as a correction term for the selection bias in the estimates of the salaries of both entrepreneurs and employees, compared with those estimated purely by Ordinary Least Squares (OLS). If the inverse Mills ratios are significant, it indicates that there was indeed a selection bias in the OLS estimates, thus necessitating intervention to correct this problem.

According to Cameron and Trivedi (2005), the method elaborated by Heckman will increase the regression in relation to that estimated by OLS, precisely because it includes a regressor omitted from an OLS estimate, represented by $\lambda_{1}$.

\subsection{Oaxaca-Blinder Decomposition}

In this section, we will analyze the wage differential between entrepreneurs and employees to quantify the contributions of differences in discrimination and productivity characteristics. Through wage differentials, we can use the Oaxaca-Blinder decomposition. In this way, a structure is created considering two groups, A (Entrepreneur) and B (employee); a dependent variable Y (wages log); and explanatory variables, including indicators such as schooling, gender, and age. Thus, we try to verify the magnitude of the average wage difference, represented by

$$
R=E\left(Y_{A}\right)-E\left(Y_{B}\right)
$$

where $E(Y)$ represents the expected value of the dependent variable, that is, the expected value of the wage computed through the differences between the groups of predictors. Another way of expressing the mean difference in wages would be through the difference in the linear prediction of the mean of the regressors of one of the groups as represented below:

\subsection{Database and Treatment}

$$
R=E\left(X_{A}\right)^{\prime} \beta_{A}-E\left(X_{B}\right)^{\prime} \beta_{B}
$$

The 2015 National Household Sample Survey (PNAD), conducted by the Brazilian Institute of Geography and Statistics (IBGE) is used for the sample data, and it is the most current available information as of the date of the present study. We excluded individuals under the age of 15 and over the age of 90 , aiming to exclude individuals who are not able to occupy the labor market. In addition, individuals who did not report any income were removed from the sample. Finally, we excluded observations with incomes either higher than R \$50,000.00 per month or less than half of the minimum wage in an attempt to eliminate possible distortions in the analysis.

As discussed by Menezes (2015), the empirical literature shows that when we study entrepreneurship it is common to verify the use of two representative proxies. Some studies point out the entrepreneur as an individual who has self-employment and works on his or her own, while others view the entrepreneur as an employer, someone who owns a business and therefore generates jobs for others. In this study, both approaches are used. The dependent variable $Y_{i}$ will assume a value of 1 for entrepreneurs, being employers or autonomous, and 0 otherwise.

To analyze the choice for the entrepreneurial option in Brazil, we use the individuals' personal, socioeconomic, and demographic characteristics. Such characteristics, selected based on the entrepreneurship literature, are used in the model as explanatory variables. The variables employed will be reported as follows: personal characteristics: gender, race, age, square of age, marital status, head of household, number of children; socioeconomic characteristics: pensioner, retired, another type of income, rental income; and finally, the demographic characteristics: urban resident, rural/agricultural area resident, metropolis resident. We created dummies variables for education level: uneducated, educl (an individual who has one to four years of study), educ2 (an individual that has education between five and eight years of study), educ3 (secondary education), and educ4 (higher education). In addition, we created dummy variables for the various regions: Southeast, South, Central-West, North, and Northeast.

Next, we estimated the wage equations. It should be noted that some variables were excluded in this process, such as incomes that do not come from paid work (retirement, pensioner, rental income, and other income) as well as number of children, following the proposal of Maddala (1986). We understand that these variables influence the choice of individuals to opt for an entrepreneurial career, but do not directly affect the determination of their salaries.

We also generated the variable hourly wage, which denotes the average remuneration of the individual per hour 
worked. According to the methodology proposed by Mincer (1974), this is calculated by dividing the salary earned from the main source of work by 4.2 (i.e., 30 days per month divided by 7 days per week). Once we have the wage or compensation per week and the same magnitude of the variable worked hours, which are computed weekly, we can divide the salary by the hours worked, thus resulting in our variable hourly wage, which will be used in the logarithmic form for the estimates.

The variable wage-hour, which expresses the average remuneration per hour worked, will be used in the Oaxaca-Blinder decomposition, which, in turn, will show us the differential of the entrepreneur's salary in relation to the salaried worker and try to explain how much each explanatory variable contributes to this differentiation.

Table 1 describes the total sample, after the exclusions and treatments, thus decomposing the individuals into two occupations: employees and entrepreneurs. A total of 126,511 individuals are analyzed period. Of these, 90,061 are salaried employees while 36,450 are engaged in entrepreneurial activity. With respect to gender, 77,302 are men $(61.10 \%)$ and 49,209 are women $(38.90 \%)$.

Table 1. Number and percentage of sampled individuals by occupation and gender

\begin{tabular}{lllllll}
\hline Occupation & Total & Men & Women & Total \% & Men \% & Women $\%$ \\
\hline Employees & 90,061 & 51,291 & 38,770 & 71.19 & 56.95 & 43.05 \\
Entrepreneurs & 36,450 & 26,011 & 10,439 & 28.81 & 91.36 & 28.64 \\
Total & 126,511 & 77,302 & 49,209 & 100 & 61.10 & 38.90 \\
\hline
\end{tabular}

Source: Prepared by the author, based on data from the 2015 PNAD。

In the database, we can highlight that among the individuals present in the sample that are 51,291 salaried workers, 38,770 represent women. In relation to the entrepreneurs, the majority is also composed of men $(26,011)$, more than twice the number of women in this occupation $(10,439)$, thus highlighting the predominance of men in entrepreneurship.

\section{Results}

In this section, we present the results generated from the probit models, yield equations, and the Oaxaca-Blinder decomposition. The objective is to determine the factors influencing the choice of entrepreneurship as an occupation in Brazil based on models of occupational choice, using the 2015 PNAD microdata. Our results can be analyzed and interpreted from an economic theory perspective, thus establishing linkages and comparing related works in the literature.

The probit model shows the roles of the observed variables in the entrepreneurial occupational choice. For a better interpretation of these variables, we include the marginal effects, since probit only allows us to analyze the signs of the coefficients. Table 2 shows the increases/decreases in the probability of an individual becoming an entrepreneur. The marginal effect column shows the percentage share of each variable's contribution to the entrepreneurial career choice.

In analyzing the first model, we highlight the results of the Wald test, which indicate that the explanatory variables are jointly important to explain the dependent variable. The model presents a good fit, given that it correctly predicts $73.20 \%$ of the events. Note that, in general, the coefficient signs were as expected, and the variables were statistically significant at the $1 \%$ significance level, except for number of children, retirement, and other types of income, which did not present statistically significant results.

Analyzing each variable separately, we find that men are $9.56 \%$ more likely to be entrepreneurs than women are. This is in line with the results of Wit and Winden (1990), Welsch and Young (1984), and Cromie (1987), who report a greater probability of men becoming entrepreneurs. Regarding race, we see that whites are $3.62 \%$ more likely to be entrepreneurs than other races are. This is in line with the findings of Borjas and Bronars (1989) and Clark and Drinkwater (1998). 
Table 2. Determinants of the entrepreneurship occupational choice in Brazil

\begin{tabular}{|c|c|c|}
\hline \multirow[t]{2}{*}{ Variables } & \multicolumn{2}{|c|}{ Probit Model 1} \\
\hline & Coefficient & Marginal Effect \\
\hline \multirow[t]{2}{*}{ Gender } & $0.3140 * * *$ & $0.0956 * * *$ \\
\hline & $(0.0124)$ & $(0.0038)$ \\
\hline \multirow[t]{2}{*}{ Race } & $0.1187 * * *$ & $0.0362 * * *$ \\
\hline & $(0.0106)$ & $(0.0032)$ \\
\hline \multirow[t]{2}{*}{ Age } & $0.0353 * * *$ & $0.0107 * * *$ \\
\hline & $(0.0022)$ & $(0.0007)$ \\
\hline \multirow[t]{2}{*}{$\mathrm{Age}^{2}$} & $-0.0001 * * *$ & $-0.0000 * * *$ \\
\hline & $(0.0000)$ & $(0.0000)$ \\
\hline \multirow[t]{2}{*}{ Educ1 } & $0.0790 * * *$ & $0.0240 * * *$ \\
\hline & $(0.0231)$ & $(0.0070)$ \\
\hline \multirow[t]{2}{*}{ Educ2 } & $0.1653 * * *$ & $0.0503 * * *$ \\
\hline & $(0.0223)$ & $(0.0068)$ \\
\hline \multirow[t]{2}{*}{ Educ3 } & $0.0958 * * *$ & $0.0292 * * *$ \\
\hline & $(0.0224)$ & $(0.0068)$ \\
\hline \multirow[t]{2}{*}{ Educ4 } & $0.1708^{* * *}$ & $0.0520 * * *$ \\
\hline & $(0.0238)$ & $(0.0073)$ \\
\hline \multirow[t]{2}{*}{ Marital status } & $0.1478 * * *$ & $0.0450 * * *$ \\
\hline & $(0.0102)$ & $(0.0031)$ \\
\hline \multirow[t]{2}{*}{ Householder } & $0.0976^{* * *}$ & $0.0297 * * *$ \\
\hline & $(0.0093)$ & $(0.0028)$ \\
\hline \multirow[t]{2}{*}{ Number of children } & 0.0101 & 0.0031 \\
\hline & $(0.0075)$ & $(0.0023)$ \\
\hline \multirow[t]{2}{*}{ Pensioner } & $0.1875^{* * *}$ & $0.0571 * * *$ \\
\hline & $(0.0380)$ & $(0.0116)$ \\
\hline \multirow[t]{2}{*}{ Retired } & 0.0389 & 0.0119 \\
\hline & $(0.0262)$ & $(0.0080)$ \\
\hline \multirow[t]{2}{*}{ Income (other) } & 0.0231 & 0.0070 \\
\hline & $(0.0227)$ & $(0.0069)$ \\
\hline \multirow[t]{2}{*}{ Rent income } & $0.4025^{* * *}$ & $0.1226^{* * * *}$ \\
\hline & $(0.0382)$ & $(0.0116)$ \\
\hline \multirow[t]{2}{*}{ Urban } & $-0.1299 * * *$ & $-0.0396 * * *$ \\
\hline & $(0.0211)$ & $(0.0064)$ \\
\hline \multirow[t]{2}{*}{ Rural } & $0.2152 * * *$ & $0.0655^{* * * *}$ \\
\hline & $(0.0290)$ & $(0.0088)$ \\
\hline \multirow[t]{2}{*}{ Metropolis } & $-0.0619 * * *$ & $-0.0188 * * *$ \\
\hline & $(0.0114)$ & $(0.0035)$ \\
\hline \multirow[t]{2}{*}{ North } & $0.3330 * * *$ & $0.1014 * * *$ \\
\hline & $(0.0170)$ & $(0.0051)$ \\
\hline \multirow[t]{2}{*}{ Northeast } & $0.1991 * * *$ & $0.0606 * * *$ \\
\hline & $(0.0141)$ & $(0.0042)$ \\
\hline South & $0.0417 * * *$ & $0.0127 * * *$ \\
\hline & $(0.0160)$ & $(0.0049)$ \\
\hline Midwest & $0.1130 * * *$ & $0.0344 * * *$ \\
\hline & $(0.0185)$ & $(0.0056)$ \\
\hline Constant & $-2.3193 * * *$ & \\
\hline & $(0.0530)$ & \\
\hline Observations & 126,511 & \\
\hline Log-Likelihood & -68681.061 & \\
\hline Test Wald & $\chi^{2}=13669.99$ & \\
\hline Predictive Classification & $73.20 \%$ & \\
\hline
\end{tabular}

Source: Prepared by the author based on PNAD data from 2015.* significant parameters at $10 \%$; ** significant parameters at $5 \%$; *** significant parameters at $1 \%$. 
The age variable is used as a proxy for experience in the labor market; as such, it increases the probability of an individual becoming an entrepreneur by $1.07 \%$ every year. However, according to Parker (2009), age squared has a negative sign, indicating that although the chances of an individual becoming an entrepreneur increase as he/she grows older, after a certain point, this probability begins to decrease, demonstrating a non-linear relationship that the literature indicates as an inverted U-shaped function.

Regarding years of study, the probability of being an entrepreneur increases with elementary education; the probability is $2.4 \%$ with incomplete primary education, which increases to $5.03 \%$ with complete primary education. An individual with high school education is $2.92 \%$ more likely to become an entrepreneur than an untrained individual (variable omitted). Furthermore, an individual with a higher education level is $5.2 \%$ more likely to be an entrepreneur, indicating, once again, an increase in the probability.

The variable householder has a positive relationship with the probability of becoming an entrepreneur, contributing to a $2.97 \%$ increase in this probability. This indicates that being the primary responsible individual in the family increases his/her likelihood of becoming an entrepreneur. This is in line with Lindh and Ohlsson (1996).

The variables linked to retirement status also show a positive relationship with the probability of becoming an entrepreneur. The variable pensioner increases the chances of engaging in entrepreneurial activities by $5.71 \%$, while retired does not present a significant result. The presence of rental income also contributes to an increase in the probability by $12.26 \%$, indicating that individuals who receive rental income are more likely to become entrepreneurs. A similar finding is provided by Menezes (2015).

Regarding the area of residence, individuals residing in a metropolitan or urban area are less likely to be entrepreneurs. Residents of urban areas have a decreased likelihood of becoming entrepreneurs, while the likelihood for residents of metropolitan areas is reduced by $1.88 \%$, thus corroborating the findings of Menezes (2015). This may indicate that the probability of getting a good job and ensuring good economic conditions is relatively higher in metropolitan regions. However, for individuals living in agricultural areas, the effect is positive, contributing to a $6.55 \%$ increase in the probability. These results are in line with those of Tamvada (2007), who highlight the importance of geographic location as an individual determinant of the entrepreneurship career choice.

Regarding demographic aspects, all region dummies presented positive signs; thus, they contribute to increasing the probability of an individual becoming an entrepreneur in the Southeast region (variable omitted). In this sense, the highest probabilities in the North and Northeast regions are $10.14 \%$ and $6.06 \%$, respectively. The Central-West and South regions show increased probabilities of becoming an entrepreneur by $3.44 \%$ and $1.27 \%$, respectively, contrary to the results of Menezes (2015).

According to the economic theory of entrepreneurship, individuals make choices to maximize their profits. According to Parker (2009), it will be interesting to determine if entrepreneurs earn relatively more than wage earners, highlighting their choice for entrepreneurial activity as a contributor to their utility maximization by ensuring a higher salary. Based on economic theory and knowledge of the labor market, we expect that an average entrepreneur earns more than an employee. Our preliminary analysis shows that entrepreneurs earn, on average, a salary of $\mathrm{R} \$ 2,183.00$ per month, and are aged 44 years. Meanwhile, salaried employees earn $\mathrm{R} \$ 1,545.00$ per month, and are aged 36 years. Thus, an entrepreneur earns approximately $29.2 \%$ higher remuneration than a salaried employee.

To better understand these results, we estimate the income equations for both categories to explain the entrepreneurial occupation choice based on the earnings relative to that of the salaried worker. We apply the Heckman method (1979) to estimate the yield equation, correcting the self-selection bias presented in the OLS estimates. In the second model, certain variables used previously are no longer used because they are not relevant for wage formation.

Table 3 presents the estimates of the wage equation. It should be noted that the Heckman model obtained more robust results than the OLS estimates, since the coefficients of variables $\lambda 1$ and $\lambda 2$ were statistically significant, indicating the presence of selection bias. Thus, the Heckman method is necessary to correct the sample selection bias in the OLS model and to ensure consistency in wage estimates. This bias is corrected by adding the inverse Mills ratio to the regression. 
Table 3. Equation of estimated wages by the Heckman and OLS methods

\begin{tabular}{|c|c|c|c|c|}
\hline \multirow[t]{2}{*}{ Variables } & \multicolumn{2}{|c|}{ Entrepreneurship } & \multicolumn{2}{|c|}{ Employees } \\
\hline & Heckman & $O L S$ & Heckman & $O L S$ \\
\hline \multirow[t]{2}{*}{ Gender } & 0.0325 & $0.1596^{* * *}$ & $0.1293 * * *$ & $0.2073 * * *$ \\
\hline & $(0.0223)$ & $(0.0094)$ & (0.0168) & $(0.0041)$ \\
\hline \multirow[t]{2}{*}{ Race } & $0.1259 * * *$ & $0.1741 * * *$ & $0.0686^{* * *}$ & $0.0983^{* * *}$ \\
\hline & $(0.0122)$ & $(0.0090)$ & $(0.0074)$ & $(0.0043)$ \\
\hline \multirow[t]{2}{*}{ Age } & $-0.0076^{* *}$ & $0.0142 * * *$ & $0.0213 * * *$ & $0.0334 * * *$ \\
\hline & $(0.0036)$ & (0.0019) & (0.0027) & $(0.0010)$ \\
\hline \multirow[t]{2}{*}{$\mathrm{Age}^{2}$} & $0.0000 *$ & $-0.0001 * * *$ & $-0.0002 * * *$ & $-0.0003 * * *$ \\
\hline & $(0.0000)$ & $(0.0000)$ & $(0.0000)$ & $(0.0000)$ \\
\hline \multirow[t]{2}{*}{ Educ1 } & -0.0213 & 0.0075 & $-0.0383 * * *$ & -0.0171 \\
\hline & (0.0199) & $(0.0181)$ & $(0.0117)$ & $(0.0105)$ \\
\hline \multirow[t]{2}{*}{ Educ2 } & $0.0849 * * *$ & $0.1460 * * *$ & $0.0648 * * *$ & $0.1078 * * *$ \\
\hline & $(0.0221)$ & $(0.0179)$ & $(0.0137)$ & $(0.0102)$ \\
\hline \multirow[t]{2}{*}{ Educ3 } & $0.3471 * * *$ & $0.3811 * * *$ & $0.2346^{* * *}$ & $0.2591 * * *$ \\
\hline & $(0.0202)$ & $(0.0183)$ & $(0.0115)$ & $(0.0102)$ \\
\hline \multirow[t]{2}{*}{ Educ4 } & $0.9095^{* * *}$ & $0.9686^{* * *}$ & $0.7711 * * *$ & $0.8121 * * *$ \\
\hline & $(0.0237)$ & $(0.0205)$ & $(0.0142)$ & $(0.0113)$ \\
\hline \multirow[t]{2}{*}{ Marital status } & $0.0746^{* * *}$ & -0.0069 & $0.0273 * * *$ & $0.0216^{* *}$ \\
\hline & $(0.0134)$ & $(0.0189)$ & $(0.0105)$ & $(0.0108)$ \\
\hline \multirow[t]{2}{*}{ Householder } & $0.0274 * *$ & $0.0715^{* * *}$ & $0.0375^{* * *}$ & $0.0635 * * *$ \\
\hline & $(0.0111)$ & $(0.0086)$ & $(0.0071)$ & $(0.0042)$ \\
\hline \multirow[t]{2}{*}{ Urban } & $0.2028 * * *$ & $0.1538 * * *$ & $0.0829 * * *$ & $0.0510 * * *$ \\
\hline & $(0.0164)$ & $(0.0147)$ & $(0.0091)$ & $(0.0068)$ \\
\hline \multirow[t]{2}{*}{ Rural } & $-0.1544 * * *$ & $-0.0825 * * *$ & $-0.2203 * * *$ & $-0.1732 * * *$ \\
\hline & $(0.0211)$ & $(0.0164)$ & $(0.0128)$ & $(0.0081)$ \\
\hline \multirow[t]{2}{*}{ Metropolis } & $0.0892 * * *$ & $0.0573 * * *$ & $0.1213 * * *$ & $0.1043^{* * *}$ \\
\hline & (0.0099) & $(0.0088)$ & $(0.0054)$ & $(0.0041)$ \\
\hline \multirow[t]{2}{*}{ North } & $-0.2910^{* * *}$ & $-0.1634 * * *$ & $-0.2122 * * *$ & $-0.1306^{* * * *}$ \\
\hline & $(0.0256)$ & $(0.0124)$ & $(0.0181)$ & $(0.0065)$ \\
\hline \multirow[t]{2}{*}{ Northeast } & $-0.3255^{* * *} *$ & $-0.2449 * * *$ & $-0.3129 * * *$ & $-0.2631 * * *$ \\
\hline & $(0.0175)$ & $(0.0112)$ & $(0.0116)$ & $(0.0052)$ \\
\hline \multirow[t]{2}{*}{ South } & -0.0027 & $0.0210^{*}$ & -0.0075 & 0.0044 \\
\hline & $(0.0126)$ & $(0.0123)$ & $(0.0064)$ & $(0.0057)$ \\
\hline \multirow[t]{2}{*}{ Midwest } & $0.0499 * * *$ & $0.0969 * * *$ & -0.0005 & $0.0281 * * *$ \\
\hline & $(0.0159)$ & $(0.0139)$ & $(0.0088)$ & $(0.0067)$ \\
\hline \multirow[t]{2}{*}{$\lambda_{1}$} & $-0.5477 * * *$ & & & \\
\hline & $(0.0958)$ & & & \\
\hline \multirow[t]{2}{*}{$\lambda_{2}$} & & & $-0.3105 * * *$ & \\
\hline & & & $(0.0664)$ & \\
\hline \multirow[t]{2}{*}{ Constant } & $2.5286^{* * *}$ & $1.1230 * * *$ & $1.6086^{* * * *}$ & $0.7976^{* * *}$ \\
\hline & $(0.2513)$ & $(0.0476)$ & $(0.1731)$ & $(0.0215)$ \\
\hline Observations & 36,450 & 36,450 & 90,061 & 90,061 \\
\hline $\mathrm{R}^{2}$ & 0.2491 & 0.2483 & 0.2835 & 0.2832 \\
\hline
\end{tabular}

Source: Prepared by the author based on data from the 2015 PNAD. Note: the standard deviations are robust to heteroskedasticity for the OLS estimates. For the robust Heckman standard deviation estimates obtained by bootstrap with 1000 replicates. * significant parameters at $10 \%$; ** significant parameters at $5 \%$; *** significant parameters at $1 \%$.

In Table 3, entrepreneurial individuals are compared against wage earners in relation to their income equation using Heckman's estimation method. It can be observed that the gender variable is not statistically significant, which indicates that the entrepreneur's gender does not influence his/her salary. However, for salaried individuals, being male contributes to earning a higher salary. Although the gender variable in the previous model indicated that men are more likely to become entrepreneurs, it is not significant in determining entrepreneurial earnings. However, further research on this variable is needed. 
For white individuals, choosing entrepreneurial activity has a greater effect on income than choosing wage labor. The race variable presents statistically significant results at the $1 \%$ significance level, highlighting that skin color still influences individual remuneration independent of labor category. This is in line with the findings of Menezes (2015), who also find the same behavior in a 2012 study.

The age variable has a negative effect on entrepreneurs. This may be because, as an individual grows older, he/she becomes more risk-averse and tends to cut down on his/her entrepreneurial activities. Another noteworthy fact, as previously noted, is that age is not a linear function. According to the theoretical framework of entrepreneurship economics, such a function would have an inverted-U shape: age contributes positively until a certain point, and thereafter, the effect turns negative.

Regarding the most crucial influencing variables, the levels of schooling showed a statistically significant result, except for the $e d u c l$ variable. This indicates a higher financial return for entrepreneurs. The variables indicate that the higher the level of education, the higher this factor's contribution to income formation, thus leading to a higher remuneration for entrepreneurs than for employees. This demonstrates the importance of education when choosing entrepreneurship.

With respect to civil status, it has a greater effect on entrepreneurs' income formation. In the present study, "married" constitutes all individuals currently living with their spouse. While this variable positively impacts the wage formation of all individuals, it has a greater effect on entrepreneurs.

Regarding the area of residence, living in an urban area contributes positively to wage wages, and the effect is stronger on entrepreneurs than on salaried workers. However, being a resident of a metropolitan area also contributes positively, but the greatest effect is for salaried individuals, which is expected given the availability of a wider range of jobs offering better working conditions and higher financial remuneration.

Analyzing the inverse Mills ratio represented in Table 3 by $\lambda_{1}$, a statistically significant result indicates that previously, there was sampling selection bias in the OLS estimates that has since been corrected, thus ensuring consistency in the estimation. Its negative sign indicates that the average entrepreneur earns higher remuneration than a random individual in the sample. According to economic theory, individuals consider occupational choice a means to maximize their utility, and thus choose the career that will bring them the most payment.

Apart from verifying if there is a wage gap between entrepreneurs and salaried workers, the detailed decomposition allows us to understand how much each observed variable, or what portion of each explanatory variable, contributes to this wage differential. The wage differential between entrepreneurs and wage earners are shown in Table 4. Analyzing the differential of the forecasts of the logarithms of the salaries for entrepreneurs, we find a value of 0.1968 , representing a differential of $19.68 \%$ between entrepreneurs and employees.

Table 4. Decomposition of the wage differential

\begin{tabular}{|c|c|c|c|}
\hline Logarithm Salary/hour & & & \\
\hline Entrepreneur & $\begin{array}{c}2.2466^{* * * *} \\
(0.0050)\end{array}$ & & \\
\hline Wage earner & $\begin{array}{c}2.0498 * * * \\
(0.0026)\end{array}$ & & \\
\hline Difference & $\begin{array}{c}0.1968 * * * \\
(0.0056) \\
\end{array}$ & & \\
\hline Explanatory variables & & $\begin{array}{c}\text { Component } \\
\text { Explained } \\
\end{array}$ & $\begin{array}{c}\text { Component } \\
\text { Not Explained }\end{array}$ \\
\hline Gender & & $\begin{array}{c}0.0132 * * * \\
(0.0022)\end{array}$ & $\begin{array}{c}-0.0645 * * * \\
(0.0199)\end{array}$ \\
\hline Race & & $\begin{array}{c}0.0028 * * * \\
(0.0004)\end{array}$ & $\begin{array}{c}0.0211 * * * \\
(0.0076)\end{array}$ \\
\hline Age & & $\begin{array}{c}0.0693 * * * \\
(0.0173)\end{array}$ & $\begin{array}{c}-1.0632 * * * \\
(0.1904)\end{array}$ \\
\hline $\mathrm{Age}^{2}$ & & $\begin{array}{c}-0.0728^{* * * *} \\
(0.0097)\end{array}$ & $\begin{array}{c}0.4429 * * * \\
(0.0594)\end{array}$ \\
\hline Educ1 & & $\begin{array}{l}-0.0014 * \\
(0.0007)\end{array}$ & $\begin{array}{l}-0.0002 \\
(0.0036)\end{array}$ \\
\hline Educ2 & & $\begin{array}{c}0.0036 * * * \\
(0.0006)\end{array}$ & $\begin{array}{c}0.0010 \\
(0.0067)\end{array}$ \\
\hline
\end{tabular}




\begin{tabular}{|c|c|c|}
\hline Educ3 & $\begin{array}{c}-0.0303 * * * \\
(0.0015)\end{array}$ & $\begin{array}{c}0.0352 * * * \\
(0.0091)\end{array}$ \\
\hline Educ4 & $\begin{array}{c}-0.0178 * * * \\
(0.0023)\end{array}$ & $\begin{array}{c}0.0211 * * * \\
(0.0062)\end{array}$ \\
\hline Marital status & $\begin{array}{c}0.0086^{* * *} \\
(0.0011)\end{array}$ & $\begin{array}{c}0.0120 \\
(0.0117)\end{array}$ \\
\hline Householder & $\begin{array}{c}0.0050 * * * \\
(0.0011)\end{array}$ & $\begin{array}{l}-0.0047 \\
(0.0082)\end{array}$ \\
\hline Urban & $\begin{array}{c}-0.0077 * * * \\
(0.0006)\end{array}$ & $\begin{array}{c}0.1087 * * * \\
(0.0185)\end{array}$ \\
\hline Rural & $\begin{array}{c}-0.0143^{* * * *} \\
(0.0010)\end{array}$ & $\begin{array}{c}0.0067 * * \\
(0.0027)\end{array}$ \\
\hline Metropolis & $\begin{array}{c}-0.0081 * * * \\
(0.0005)\end{array}$ & $\begin{array}{c}-0.0147 * * * \\
(0.0041)\end{array}$ \\
\hline North & $\begin{array}{c}-0.0073^{* * *} * \\
(0.0006)\end{array}$ & $\begin{array}{c}-0.0064 * * \\
(0.0028)\end{array}$ \\
\hline Northeast & $\begin{array}{c}-0.0086^{* * * *} \\
(0.0009)\end{array}$ & $\begin{array}{l}-0.0036 \\
(0.0050)\end{array}$ \\
\hline South & $\begin{array}{l}-0.0000 \\
(0.0000)\end{array}$ & $\begin{array}{c}0.0026 \\
(0.0024)\end{array}$ \\
\hline Midwest & $\begin{array}{c}0.0000 \\
(0.0000)\end{array}$ & $\begin{array}{c}0.0049 * * * \\
(0.0016)\end{array}$ \\
\hline$\lambda_{1}$ & $\begin{array}{c}0.1134 * * * \\
(0.0158)\end{array}$ & $\begin{array}{c}-0.2981 * \\
(0.1534)\end{array}$ \\
\hline Constant & & $\begin{array}{c}0.9485 * * * \\
(0.3377)\end{array}$ \\
\hline Total & $\begin{array}{c}0.0474 * * * \\
(0.0032)\end{array}$ & $\begin{array}{c}0.1494 * * * \\
(0.0050)\end{array}$ \\
\hline
\end{tabular}

Observations 126,511

Source: Prepared by the author based on PNAD data from $2015 . *$ significant parameters at $10 \%$; ** significant parameters at $5 \%$; *** significant parameters at $1 \%$.

The results in Table 4 show that the average entrepreneur has a salary approximately $20 \%$ higher than that of an employee, in line with expectations. The characteristics observed in the detailed decomposition can be divided into two groups: those that contribute to a higher salary for entrepreneurs and those that contribute to a reduction in this difference. Adding the two groups creates a balance in the salary gap between the two categories (entrepreneurs and wage earners).

In the first group, the Age variable contributes the most to the differential increase at $6.9 \%$, indicating that there is a tendency for entrepreneurs to be older and to earn more for their years of experience. This corroborates previous findings, which indicate that entrepreneurs are, on average, older than salaried workers.

Gender also contributes to the increase in the differential. Being male contributes to a $1.32 \%$ increase in the differential. When analyzed in conjunction with the race variable-which indicates that being white increases the wage differential by $0.28 \%$ - we find that being male and white implies a higher salary for the entrepreneur than for the salaried worker. Being responsible for one's family contributes to the entrepreneur earning more than the salaried worker (approximately $0.50 \%$ ). The civil status variable contributes to increasing the salary gap by $0.86 \%$. Finally, the variable $e d u c 2$, the last in this group of characteristics, contributes to a $0.36 \%$ increase in the wage gap between entrepreneurs and wage earners.

Next, we turn to the second group. We emphasize the contribution of schooling, or the years of study. The variable educ3, which indicates the individual has completed high school, reduces the wage differential between entrepreneurs and employees by $3.03 \%$, the largest value in this group. Moreover, the individual obtaining higher levels of education reduces the gap by $1.78 \%$. Thus, it is reasonable to assume that an individual with a higher level of education can achieve a higher-valued job and thus earn a higher salary.

Regarding the area of residence, residing in an agricultural area reduces the wage differential by $1.43 \%$. If the individual lives in an urban area, the reduction of the wage gap is smaller-only $0.77 \%$-indicating that the inhabitants of agricultural areas contribute to a greater reduction in the wage difference. Being a resident of a 
metropolis reduces the salary difference by $0.81 \%$; this can be attributed to a greater range of employment opportunities with higher remuneration. Regarding the regional dummies, the North and Northeast are statistically significant, reducing the wage gap by $0.73 \%$ and $0.8 \%$, respectively. These results indicate that residing in either of these two regions reduces the wage differential between entrepreneurs and wage earners.

The results are as expected, with almost all the variables presenting statistically significant values at the $1 \%$ significance level, thus providing a better understanding of individuals' entrepreneurial career choice. They also well explain the salary gap between these two groups in the Brazilian context.

\section{Final Considerations}

Entrepreneurship economics provides insights into the individual constraints regarding the entrepreneurship career choice in developed countries. This study analyzed the determining factors for the salary differential between entrepreneurs and wage earners in Brazil. Estimating the income equations for entrepreneurs and employees, along with a detailed decomposition, we contribute to a relatively unexplored aspect of the Brazilian literature.

Analyzing the determinants of entrepreneurship highlighted in the literature, we obtained expected results regarding the effect of most coefficients, which are in line with the findings of previous works. Regarding the wage differential, the results confirm that entrepreneurs earn a higher salary than salaried workers, justifying indiividuals' choice of an entrepreneurial career.

In fact, those who opt for an entrepreneurial career earn higher remuneration than salaried workers, even when the individuals have the same characteristics. The explanatory variables or characteristics chosen for analysis contribute to increasing or reducing this salary gap. However, it should be noted that other influential unobserved factors exist, such as entrepreneurial drive and dedication to work, as well as several other characteristics that have not been studied in this work, either because of the difficulty of measurement or simply because of a lack of data.

Through a detailed Oaxaca-Blinder decomposition, we analyze how each explanatory variable contributes to the formation of this wage gap, identifying the variables that have the most impact. This makes the research attractive for managers of public policies, who aim to foster entrepreneurship in order to generate employment, wealth formation, and thereby leverage economic growth.

This study analyzed a segment that has not yet been explored in the literature; thus, it was difficult to find works specifically related to this subject, and which establish a relationship between entrepreneurs and wage earners while focusing on the wage gap. By emphasizing the significance of this topic, our study makes a small contribution to the broader literature. Many studies regarding the wage differential between men and women exist. In the future, we propose to conduct an analysis by gender among entrepreneurs. The results of this study also highlight the need for analysis by region, given that Brazil is a country with continental dimensions, and it can be expected that different regions will show different results on this subject.

Finally, this work sought to establish a link across the entrepreneurship economics literature, using a less explored niche in the Brazilian context and providing insightful results for analysts, managers of public policies, and researchers. In this way, one can allocate incentives in the search for fomenting entrepreneurial activity since it is directly linked to economic growth.

\section{References}

Afandi, E., \& Kermani, M. (2015). Bridging the gender gap in entrepreneurship: an empirical analysis. Journal $\begin{array}{llll}\text { of Developmental } & \text { Entrepreneurship, } & 20(2), & 1550008 .\end{array}$ https://doi.org/https://doi.org/10.1142/S1084946715500089

Almeida, W. da S. de, \& Besarria, C. N. (2014). Diferenciais De Rendimento Por Gênero E Raça: Uma Análise Via Regressões Quantílicas E Decomposição De Oaxaca-Blinder (1973). X Encontro De Economia Baiana, (1973), 349-373.

Bartalotti, O. A. C. (2007). Discriminação salarial por cor e gênero revisitada: uma abordagem de decomposição contrafactual utilizando regressões quantílicas. Fundação Getúlio Vargas. http://hdl.handle.net/10438/1784

Bernat, L. F., Lambardi, G., \& Palacios, P. (2016). Determinants of the entrepreneurial gender gap in Latin America. Small Business Economics, 48(3), 727-752. https://doi.org/10.1007/s11187-016-9789-7

Blanchflower, D. (2004). Self-Employment: More may not be better. Climate Change 2013 - The Physical Science Basis, (February), 1-30. https://doi.org/10.3386/w10286 
Blinder, A. S. (1973). Wage Discrimination: Reduced Form and Structural Estimates. The Journal of Human Resources, 8(4), 436-455. https://doi.org/10.2307/144855

Bönte, W., \& Piegeler, M. (2013). Gender gap in latent and nascent entrepreneurship: Driven by competitiveness. Small Business Economics, 41(4), 961-987. https://doi.org/10.1007/s11187-012-9459-3

Borjas, G. J., \& Bronars, S. (1989). Consumer Discrimination and Self-Employment. Journal of Political Economy, 97(3), 581-605. https://doi.org/10.1086/261617

Cacciamali, M. C., Tatei, F., \& Rosalino, J. W. (2009). Estreitamento dos Diferenciais de Salários e Aumento do Grau de Discriminação: Limitações da Mensuração Padrão? Planejamento e Políticas Públicas, 195-222. Retrieved from http://www.ipea.gov.br/ppp/index.php/PPP/article/view/159

Caliendo, M., Fossen, F. M., Kritikos, A., \& Wetter, M. (2014). The gender gap in entrepreneurship: Not just a matter of personality. CESifo Economic Studies, 61(1), 202-238. https://doi.org/10.1093/cesifo/ifu023

Carneiro, P., Heckman, J. J., \& Masterov, D. V. (2005). Labor Market Discrimination and Racial Differences in Premarket Factors. The Journal of Law and Economics, 48(1), 1-39. https://doi.org/10.1086/426878

Chatterjee, C., \& Ramu, S. (2018). Gender and its rising role in modern Indian innovation and entrepreneurship. IIMB Management Review, 30(1), 62-72. https://doi.org/10.1016/j.iimb.2017.11.006

Clark, K., \& Drinkwater, S. (1998). Ethnicity and Self-Employment in Britain. Oxford Bulletin of Economics and Statistics, 60(3), 383-407. https://doi.org/10.1111/1468-0084.00105

Colombo, M. G., \& Piva, E. (2020). Start-ups launched by recent STEM university graduates: The impact of university education on entrepreneurial entry. Research Policy, 49(6), 103993. https://doi.org/10.1016/j.respol.2020.103993

Crespo, A. R. V., \& Reis, M. C. (2004). Decomposição do componente de discriminação na desigualdade de rendimentos entre raças nos efeitos idade, período e coorte. ENCONTRO NACIONAL DA ANPEC. Natal: ANPEC.

Cromie, S. (1987). Similarities and Differences between Women and Men Business Proprietorship. International Small Business Journal, 5(3), 43-60. https://doi.org/10.1177/026624268700500304

Dornelas, J. (2014). Empreendedorismo, transformando ideias em negócios. Rio de Janeiro: LTC.

Dou, X., Zhu, X., Zhang, J. Q., \& Wang, J. (2019). Outcomes of entrepreneurship education in China: A customer experience management perspective. Journal of Business Research, 103(February), 338-347. https://doi.org/10.1016/j.jbusres.2019.01.058

Elam, A., \& Terjesen, S. (2010). Gendered Institutions and Cross-National Patterns of Business Creation for Men and Women. The European Journal of Development Research, 22(3), 331-348. https://doi.org/https://doi.org/10.1057/ejdr.2010.19

Fairlie, R. W. (2005). An extension of the Blinder-Oaxaca decomposition technique to logit and probit models. Journal of Economic and Social Measurement, 30(873), 305-316. https://doi.org/10.3233/JEM-2005-0259

Fakult, W., Tamvada, J. P., \& Delhi, N. (2007). Essays on Entrepreneurship and Economic Development Eidesstattliche Erklärung.

Fossen, F. (2009). Gender differences in entrepreneurial choice and risk aversion. Retrieved from http://www.iab.de/en/publikationen/weitere-publikationen/weitere-publikationen-details.aspx/Publikation/K 091022P04

Fritsch, M., S. Kritikos, A., \& Sorgner, A. (2015). Why did self-employment increase so strongly in Germany?

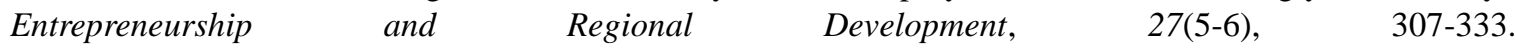
https://doi.org/10.1080/08985626.2015.1048310

Galvão, A. R., Marques, C. S. E., Ferreira, J. J., \& Braga, V. (2020). Stakeholders' role in entrepreneurship education and training programmes with impacts on regional development. Journal of Rural Studies, 74(February 2019), 169-179. https://doi.org/10.1016/j.jrurstud.2020.01.013

Gieure, C., Benavides-Espinosa, M. del M., \& Roig-Dobón, S. (2020). The entrepreneurial process: The link between intentions and behavior. Journal of Business Research, 112(November), 541-548. https://doi.org/10.1016/j.jbusres.2019.11.088

Giuberti, A. C., \& Menezes-Filho, N. (2005). Discriminação de rendimentos por gênero: uma comparação entre o Brasil e os Estados Unidos. Economia Aplicada, 9(3). https://doi.org/10.1590/S1413-80502005000300002 
Hackman, J. J. (1979). Sample Selection Bias as a Specification Error. Econometrica, 47(1), 153-161. https://doi.org/10.2307/1912352

IBGE. (2018). Pesquisa Nacional de Amostra por Domicílios (PNAD) 2015.

Lindh, T., \& Ohlsson, H. (1996). Self-Employment and Windfall Gains: Evidence from the Swedish Lottery. The Economic Journal, 106(439), 1515-1526. https://doi.org/10.2307/2235198

Llussá, F. (2011). Determinants of Entrepreneurship: Are Women Different? In FEUNL Working Paper Series. Universidade Nova de Lisboa, Faculdade de Economia. Retrieved from http://fesrvsd.fe.unl.pt/WPFEUNL/WP2011/Wp555.pdf

Maddala, G. S. (1986). Limited-Dependent and Qualitative Variables in Econometrics. Cambridge University Press. Retrieved from https://econpapers.repec.org/RePEc:cup:cbooks:9780521338257

Mahfud, T., Triyono, M. B., Sudira, P., \& Mulyani, Y. (2020). The influence of social capital and entrepreneurial attitude orientation on entrepreneurial intentions: the mediating role of psychological capital. European

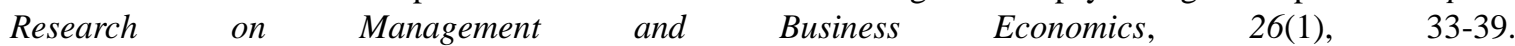
https://doi.org/10.1016/j.iedeen.2019.12.005

Meireles, D. C. (2014). Diferenciais de rendimentos por gênero: uma análise dos efeitos composição e estrutura salarial no Brasil (1976, 1987, 1996 e 2009). Universidade Federal do Rio Grande do Norte.

Menezes, G. R. (2015). Ensaios Sobre Economia do Empreendedorismo. Universidade Federal do Rio Grande do Sul.

Mincer, J. A. (1974). Schooling and Earnings. Schooling, Experience, and Earnings, I, 41-63. https://doi.org/0-870-14265-8

Monteith, W., \& Camfield, L. (2019). Business as family, family as business: Female entrepreneurship in Kampala, Uganda. Geoforum, 101(February), 111-121. https://doi.org/10.1016/j.geoforum.2019.03.003

Niederle, M., \& Vesterlund, L. (2007). Do Women Shy Away from Competition? Do Men Compete Too Much? The Quarterly Journal of Economics, 122(3), 1067-1101. https://doi.org/10.1162/qjec.122.3.1067

Oaxaca, R. (1973). Male-Female Wage Differentials in Urban Labor Markets. International Economic Review, 14(3), 693-709. https://doi.org/10.2307/2525981

Parker, S. C. (2004). The economics of self-employment and entrepreneurship. The Economics of Self-Employment and Entrepreneurship. https://doi.org/10.1017/CBO9780511493430

Parker, S. C. (2009). The economics of entrepreneurship. In C. U. (Ed.), The Economics of Entrepreneurship (First). Cambridge University Press. https://doi.org/10.1017/CBO9780511817441

Pereira, R. M., \& Oliveira, C. A. de. (2016). Os diferenciais de salário por gênero no Rio Grande do Sul: Uma aplicação do Modelo de Heckman e da Decomposição de Oaxaca-Blinder. Redes, 21(1), 148-173. https://doi.org/10.17058/redes.v21i1.3583

Poblete, C., Sena, V., \& Fernandez de Arroyabe, J. C. (2019). How do motivational factors influence entrepreneurs' perception of business opportunities in different stages of entrepreneurship? European Journal of Work and Organizational Psychology, 28(2), 179-190. https://doi.org/10.1080/1359432X.2018.1564280

Rosca, E., Agarwal, N., \& Brem, A. (2020). Women entrepreneurs as agents of change: A comparative analysis of social entrepreneurship processes in emerging markets. Technological Forecasting and Social Change, 157(March), 120067. https://doi.org/10.1016/j.techfore.2020.120067

Schumpeter, J. A. (1997). Teoria Do Desenvolvimento Econômico - Uma Investigação Sobre Lucros, Capital, Crédito, Juro e O Ciclo Econômico. Editora Nova Cultural Ltda.

Silva, J. de S., \& Lima, J. R. F. de. (2012). Discriminação por gênero no mercado de trabalho paraibano: Uma aplicação do método de Oaxaca-Blinder. In XVIII Encontro Nacional de Estudos Populacionais (ABEP). Águas de Lindóia / SP.

Tamvada, von J. P. (2007). Entrepreneurship and Economic Development Dissertation. Universität Göttingen vorgelegt.

Terjesen, S., \& Espinosa, J. A. (2010). Female Entrepreneurship in Latin America and the Caribbean: Characteristics, Drivers and Relationship to Economic Development. The European Journal of Development Research, 22(3), 313-330. https://doi.org/10.1057/ejdr.2010.13 
Van der Zwan, P., Verheul, I., \& Thurik, A. R. (2012). The entrepreneurial ladder, gender, and regional development. Small Business Economics, 39(3), 627-643. https://doi.org/10.1007/s11187-011-9334-7

Verheul, I., Thurik, R., Grilo, I., \& Van der Zwan, P. (2012). Explaining preferences and actual involvement in self-employment: Gender and the entrepreneurial personality. Journal of Economic Psychology, 33(2), 325-341. https://doi.org/10.1016/j.joep.2011.02.009

Welsch, H., \& Young, E. (1984). Male and Female Entrepreneurial Characteristics and Behaviours: A Profile of Similarities and Differences. International Small Business Journal, 2(4), 11-20.

Wit, G., \& Winden, F. Van. (1990). An empirical analysis of self-employment in the Netherlands. Economics Letters, 32, 97-100. https://doi.org/10.1016/0165-1765(90)90056-7

\section{Copyrights}

Copyright for this article is retained by the author(s), with first publication rights granted to the journal.

This is an open-access article distributed under the terms and conditions of the Creative Commons Attribution license (http://creativecommons.org/licenses/by/4.0/). 